\title{
First occurrence of Panthera atrox (Felidae, Pantherinae) in the Mexican state of Hidalgo and a review of the record of felids from the Pleistocene of Mexico
}

\author{
Victor Manuel Bravo-Cuevas ${ }^{1}$, Jaime Priego-Vargas ${ }^{2}$, Miguel Ángel Cabral-Perdomo ${ }^{1}$, and Marco Antonio Pineda \\ Maldonado $^{3}$ \\ ${ }^{1}$ Museo de Paleontología, Área Académica de Biología, Universidad Autónoma del Estado de Hidalgo, Ciudad del \\ Conocimiento, Carretera Pachuca-Tulancingo km 4.5, CP 42184, Pachuca, Hidalgo, Mexico \\ ${ }^{2}$ Área Académica de Biología, Doctorado en Biodiversidad y Conservación, Universidad Autónoma del Estado de Hidalgo, \\ Ciudad del Conocimiento, Carretera Pachuca-Tulancingo km 4.5, CP 42184, Pachuca, Hidalgo, Mexico \\ ${ }^{3}$ Área Académica de Biología, Maestría en Biodiversidad y Conservación, Universidad Autónoma del Estado de Hidalgo, \\ Ciudad del Conocimiento, Carretera Pachuca-Tulancingo km 4.5, CP 42184, Pachuca, Hidalgo, Mexico
}

Correspondence to: Victor Manuel Bravo-Cuevas (vmbc1@yahoo.com)

Received: 26 May 2016 - Revised: 18 June 2016 - Accepted: 1 July 2016 - Published: 20 July 2016

\begin{abstract}
Panthera atrox was a common large-sized cat in North America during the late Pleistocene. An isolated lower canine and a fifth metacarpal bone referable to this species were recovered from fluvial Quaternary deposits that outcrop in southeastern Hidalgo, central Mexico. Associated fossil material belonging to Bison indicates a Rancholabrean North American Land Mammal Age; the age assignment is corroborated by the presence of $P$. atrox. A comparative study with selected specimens of Panthera and Smilodon indicates that the Hidalgoan sample shares the following diagnostic features with $P$. atrox: a large, robust, and non-strongly curved lower canine; a large and relatively slender fifth metacarpal with a well-developed projection on the palmar side at the proximal end, narrow articulating surface for the unciform; a narrow notch on the articulating surface for the fourth metacarpal; and a diaphysis that at the middle is oval in cross section. The record supplements the evidence of $P$. atrox in central Mexico and represents the first reported occurrence of this cat species in the state of Hidalgo. By the same token, the known geographic distribution of $P$. atrox in the Mexican territory suggests that it was relatively common in temperate areas of central Mexico between 19 and $24^{\circ} \mathrm{N}$ at an altitudinal range from 1500 to $2250 \mathrm{~m}$ a.s.l. The large size (mean body mass of $300 \mathrm{~kg}$ ) and hypercarnivorous adaptations of the American lion suggest it was the top predator of the mammalian community recorded at southeastern Hidalgo, displacing other members of the carnivore guild at
\end{abstract}

the mesopredator level, such as the dire wolf (Canis dirus ), which has been also reported in the area. The high diversity of large herbivores recorded at southeastern Hidalgo, which in turn could represent potential prey of $P$. atrox, suggests that some areas that now are part of central Mexico were suitable hunting sites for this large-sized cat.

A review of the Pleistocene record of Felidae from Mexico revealed that it encompasses 87.5 and $73.3 \%$ of generic and specific diversity known for North America, respectively, including seven genera (Felis, Miracinonyx, Panthera, Puma, Lynx, Leopardus, and Smilodon) and 11 species (Felis rexroadensis, Miracinonyx inexpectatus, Panthera atrox, Panthera onca, Puma concolor, Puma yagouaroundi, Lynx rufus, Leopardus pardalis, Leopardus wiedii, Smilodon fatalis, and Smilodon gracilis). The majority of these taxa have been reported from numerous late Pleistocene localities; in particular, Panthera atrox was relatively common and widely distributed across the Mexican territory.

\section{Introduction}

The subfamily Pantherinae is a group of large-sized cats that originated in Asia (probably in some part of what is now China) during the end of the Miocene and at the beginning of the Pliocene (10.8-3.8 Ma) (Johnson et al., 2006; Davis et al., 
2010; Tseng et al., 2016). This group of felids includes six extant species in the genera Panthera (P. leo (African lion), $P$. tigris (tiger), P. onca (jaguar), and P. pardus (leopard)), Uncia (U. uncia (snow leopard)), and Neofelis (N. nebulosa (clouded leopard)) (Davis et al., 2010; King and Wallace, 2014); all of these species are considered to be vulnerable, endangered, and/or threatened (IUCN, 2015). Extinct pantherines include the Pleistocene species $P$. gombaszoegensis (eastern Africa), P. fossilis (Eurasia), P. youngi (northeastern China), P. spelaea (Eurasia and Alaska), and P. atrox (North America) (Kurtén and Anderson, 1980; Lange, 2002; Kurtén, 2009; Tseng et al., 2016). The oldest known pantherines are those referable to $P$. blytheae from the late Miocene-early Pliocene of the Himalayan region (Tseng et al., 2016) and $P$. palaeosinensis from the Plio-Pleistocene of China (Mazák, 2010).

The late Pleistocene species $P$. atrox was a common largesized cat in the North American subcontinent, which has been traditionally referred to as the American lion (Kurtén and Anderson, 1980). Ancestors of the American lion apparently crossed from Asia to Alaska sometime during the Illinoian glacial stage (191000 to 130000 years ago) (Lange, 2002) at the beginning of the Rancholabrean North American Land Mammal Age (NALMA). Early representatives of P. atrox appeared during the Sangamonian interglacial stage, reaching areas of southern temperate North America in a relatively short time (ca. 125000 years ago) (Kurtén and Anderson, 1980; Lange, 2002). In the Wisconsinan (7500010000 years ago) at the end of the Rancholabrean NALMA, P. atrox spread across the United States and Mexico (Kurtén and Anderson, 1980), and its southernmost occurrence has been recorded in tropical areas of the Mexican territory (Montellano-Ballesteros and Carbot-Chanona, 2009; CarbotChanona and Gómez-Pérez, 2014).

The phylogenetic status of Panthera atrox is controversial, given that some authors have considered it to have been closely related to jaguars (Simpson, 1941; Christiansen and Harris, 2009) and others that it was a subspecies of the extant lion (Kurtén and Anderson, 1980). Recent studies on the phylogenetic relationship of $P$. atrox with other members of the genus Panthera indicate that it should be considered as a separate species closely related to lions (P. leo) and tigers ( $P$. tigris) (Barnett et al., 2009; Christiansen and Harris, 2009; King and Wallace, 2014).

Information regarding the fossil material, description, and formal taxonomic characterization of Mexican specimens referable to $P$. atrox is unknown in many instances. Hence, the purpose of this study is to formally describe the dental and postcranial material belonging to Panthera atrox from the late Pleistocene of southeastern Hidalgo, central Mexico, as well as to discuss some ecological and geographic aspects of the record. Furthermore, a review of the record of felids from the Pleistocene of Mexico is provided.

\section{Study area}

The material considered here has been recovered from a locality formally known as El Barrio (HGO-47: $20^{\circ} 07^{\prime} 41^{\prime \prime} \mathrm{N}$, $98^{\circ} 56^{\prime} 02.7^{\prime \prime} \mathrm{W}$ ) in the southeastern region of Hidalgo, central Mexico (Fig. 1a). In this region Tertiary to Quaternary volcanic and volcano sedimentary rock units crop out (INEGI, 1992). The fossil-bearing strata consist of heterogeneous clastic material, including clay, silt, sand, and scarce conglomeratic lenses, setting in a fluvial depositional environment (Fig. 1b).

The associated mammalian fauna includes dire wolves (Canis dirus), giant armadillos (Glyptotherium floridanum), giant ground sloths (Paramylodon cf. harlani), llamas (Hemiauchenia gracilis and Camelops sp.), horses (Equus conversidens), pronghorns (Stockoceros conklingi and Capromeryx minor), deer (Odocoileus cf. virginianus), bison (Bison sp.), gomphotheres (Cuvieronius sp.), and mammoths (Mammuthus sp.) (Bravo-Cuevas, 2001, 2002; Bravo-Cuevas et al., $2009,2011,2012,2013)$. There is evidence of material belonging to the genus Bison, including a horn core fragment and an isolated tooth; the presence of this taxon is indicative of a Rancholabrean NALMA (Bell et al., 2004). The biochronological age of the fossil assemblage is supported by the presence of material belonging to Panthera atrox (present study).

\section{Materials and methods}

The sample consists of an isolated canine and a metacarpal bone. The material is housed at the Sección de Macrovertebrados, Museo de Paleontología, Universidad Autónoma del Estado de Hidalgo, México, with the catalogue numbers UAHMP-4221 and UAHMP-4222, respectively.

The anteroposterior and transverse diameters of the isolated tooth were measured. The measurements of the metacarpal are those of Merriam and Stock (1932: table 62, p. 134). Measurements in millimeters were taken using a digital caliper with a measuring range of $0-150 \mathrm{~mm}$, a resolution of $0.01 \mathrm{~mm}$, and an accuracy of $0.003 \mathrm{~mm}$.

In order to assess the taxonomic identity of the dental and postcranial remains from Hidalgo, we performed a comparative study with selected specimens of Panthera atrox housed at the George C. Page Museum, La Brea Discoveries, Museum of Natural History of Los Angeles County (LACM), California, USA. Additional comparisons were done with specimens belonging to the extant species P. leo (OCMP080) and P. tigris (OCMP-077) housed at the Osteological Collection of the Museo de Paleontología, Universidad Autónoma del Estado de Hidalgo. Furthermore, the Hidalgoan material was compared with specimens described and figured in Merriam and Stock (1932), Whitmore and Foster (1967), and Montellano-Ballesteros and Carbot-Chanona (2009). 

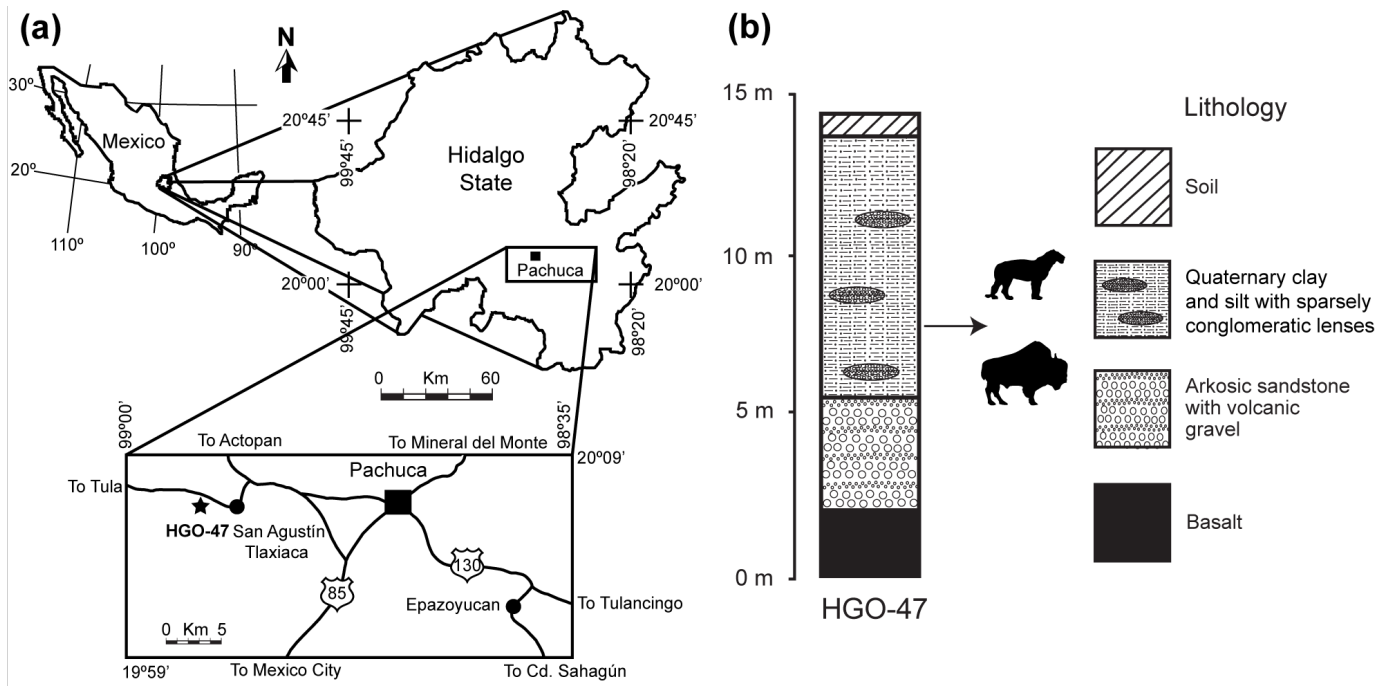

Figure 1. (a) Index map showing the study area in southeastern Hidalgo, central Mexico; the capital of the state (Pachuca) and the late Pleistocene locality El Barrio (HGO-47) are depicted. (b) Stratigraphic section of the El Barrio locality (HGO-47); the arrow indicates the fossil-bearing level.

In order to review the Pleistocene record of Felidae from Mexico, we performed a bibliographic search in primary sources (journal articles, books, and book chapters), secondary sources (abstracts, catalogs, and theses), and databases (The Paleobiology Database (https://paleobiodb. org) and the Mexican Quaternary Mammals Database; Arroyo-Cabrales et al., 2005). The collected data were arranged in terms of its generic and specific diversity, representing the basis of a distribution map of the known (so far) Pleistocene felids from the Mexican territory.

\section{Systematic paleontology}

- Order Carnivora Bowdich, 1821

- Family Felidae Fischer, 1817

- Subfamily Pantherinae Pockock, 1917

- Genus Panthera Oken, 1816

- Panthera atrox Leidy, 1853

Referred material. El Barrio locality: UAHMP-4221, left lower canine; UAHMP-4222, left fifth metacarpal.

Distribution and age. The American lion was widely distributed across North America from Alaska (Whitmore and Foster, 1967) to southern Mexico (Montellano-Ballesteros and Carbot-Chanona, 2009; Carbot-Chanona and GómezPérez, 2014); some records from Alaska and western Canada maybe represent members that are more closely related to the cave lion (P. spelaea) (Barnett et al., 2009). It is a taxon limited to the Rancholabrean NALMA (Kurten and Anderson, 1980; Lange, 2002).

\subsection{Description}

The canine UAHMP-4221 is large and robust (Table 1). A thin layer of enamel $(<1 \mathrm{~mm}$ thick) covers the first third of the tooth. The tip has broken anterolaterally after death (given that it does not show wear) and is subacute in shape. The specimen is moderately curved, and in cross section it is oval to oval-elongate toward to the base. The lateral surface of the tooth is slightly convex, whereas the medial surface is flattened (Fig. 2).

The metacarpal UAHMP-4222 is slender and long, showing a relatively gracile appearance (Table 2, Fig. 3). The shaft is oval in cross section and without sharply defined borders between the dorsal and palmar surfaces. At the proximal end, the articular surface for the unciform is narrow. The medial face presents the articular surface for metacarpal IV, formed by a large projection ("ear-shaped projection" of Merriam and Stock, 1932) and a narrow notch placed on the palmar side. The lateral surface presents a convex tuberosity. At the distal end, the lateral tuberosity is more prominent than the medial tuberosity. The distal articulation surface is situated at a $10^{\circ}$ angle from the axis of the shaft and a prominent palmar keel is apparent.

\subsection{Taxonomic assessment}

The deciduous lower canine of felids is distinguished by having an accessory cusp situated on the anterolingual side of the tooth (Salles, 1992). The specimen UAHMP-4221 does not show this condition, indicating that it is a permanent tooth; furthermore, it resembles the lower canine of pantherines in the absence of a lingual cavity (a widespread condition among felids), and differs from an upper canine in the ab- 
Table 1. Comparison of measurements (in mm) in UAHMP-4221 and lower canine specimens of Panthera atrox (a-d) and the extant species P. tigris (e) and P. leo (f). Rancholabrean localities: (a) El Barrio, southeastern Hidalgo, central Mexico (present study); (b) Lost Chicken Creek, Alaska, United States (Whitmore and Foster, 1967: table 1, p. 250); (c) Rancho La Brea, California, United States (Merriam and Stock, 1932: table 94, p. 177); and (d) La Tejería, Chiapas, southern Mexico (Montellano-Ballesteros and Carbot-Chanona, 2009: table 1, p. 219). Abbreviations: $\mathrm{AD}$, anteroposterior diameter; $\mathrm{TD}$, transverse diameter.

\begin{tabular}{ccccccc}
\hline & $\begin{array}{c}\text { (a) } \\
\text { UAHMP-4221 } \\
\text { Left }\end{array}$ & $\begin{array}{c}\text { (b) } \\
\text { USN-23619 } \\
\text { Right }\end{array}$ & $\begin{array}{c}\text { Rancho La Brea } \\
(N=11)\end{array}$ & $\begin{array}{c}(\text { IHNFG-2678 } \\
\text { Right }\end{array}$ & $\begin{array}{c}\text { (e) } \\
\text { OCMP-077 } \\
\text { Left }\end{array}$ & $\begin{array}{c}\text { OCMP-080 } \\
\text { Right/left }\end{array}$ \\
\hline AD & 30.1 & 30.0 & $21.8-30.4$ & 21.9 & 20.8 & $21.0 / 20.7$ \\
TD & 21.6 & 21.5 & $15.1-21.6$ & 15.6 & 14.2 & $13.9 / 13.7$ \\
\hline
\end{tabular}

Table 2. Comparison of measurements (in mm) between UAHMP-4222 and fifth metacarpal specimens of Panthera atrox from Rancho La Brea (RLB), late Pleistocene of California, United States (Merriam and Stock, 1932: table 62, p. 134). The observed range in the specimens from Rancho La Brea is in parentheses.

\begin{tabular}{|c|c|c|c|}
\hline & $\begin{array}{l}\text { UAHMP-4222 } \\
\text { Left }\end{array}$ & $\begin{array}{l}\text { RLB } \\
\text { Right }\end{array}$ & $\begin{array}{l}\text { RLB } \\
\text { Left }\end{array}$ \\
\hline Greatest length & 105.9 & $\begin{array}{l}x=105 \\
(90.6-115.3)\end{array}$ & $\begin{array}{l}x=106.6 \\
(91.7-113.0)\end{array}$ \\
\hline Greatest transverse diameter of proximal end & 28.4 & $\begin{array}{l}28.7 \\
(25.1-27.7)\end{array}$ & $\begin{array}{l}x=27.8 \\
(24.9-30.0)\end{array}$ \\
\hline Greatest dorsoventral diameter of proximal end & 26.8 & $\begin{array}{l}x=31.3 \\
(27.0-30.8)\end{array}$ & $\begin{array}{l}x=29.8 \\
(27.3-33.2)\end{array}$ \\
\hline Transverse diameter at middle of shaft & 17.0 & $\begin{array}{l}x=17.0 \\
(14.2-15.8)\end{array}$ & $\begin{array}{l}x=16.3 \\
(14.2-17.6)\end{array}$ \\
\hline Dorsoventral diameter at middle of shaft & 13.9 & $\begin{array}{l}x=15.0 \\
(13.2-15.2)\end{array}$ & $\begin{array}{l}x=14.1 \\
(12.2-15.8)\end{array}$ \\
\hline Greatest transverse diameter at distal end of shaft & 23.5 & $\begin{array}{l}x=24.9 \\
(21.2-25.2)\end{array}$ & $\begin{array}{l}x=24.8 \\
(22.2-25.2)\end{array}$ \\
\hline
\end{tabular}

sence of a lingual ridge (Salles, 1992) and in being more robust. By contrast, the lower canine of Smilodon is smaller and slender, strongly curved, and shows a median lateral ridge (Merriam and Stock, 1932).

The size of the tooth is comparable to that observed for lower canines belonging to Panthera atrox, including USNM 23619 (right lower jaw with c, p3-m1) from Lost Chicken Creek, Rancholabrean of Fairbanks, Alaska; it falls in the upper limit of the observed range in specimens from Rancho La Brea, California, United States; and it is nearly $25 \%$ larger than the specimen IHNFG-2678 (isolated lower canine) from Chiapas, southern Mexico (Table 1). The difference in size between the specimens from Hidalgo and Chiapas could be explained by intraspecific variation (related to age and/or sex), considering that UAHMP-4221 shows dimensions comparable to the larger lower canines from Rancho La Brea, whereas the dimensions of IHNFG-2678 correspond to those of the smaller ones (Table 1). It should be stated that the specimen UAHMP-4221 is significantly larger (ca. 33\%) than lower canines of Panthera leo and P. tigris; however, the size of this tooth between those extant species is similar (Table 1).

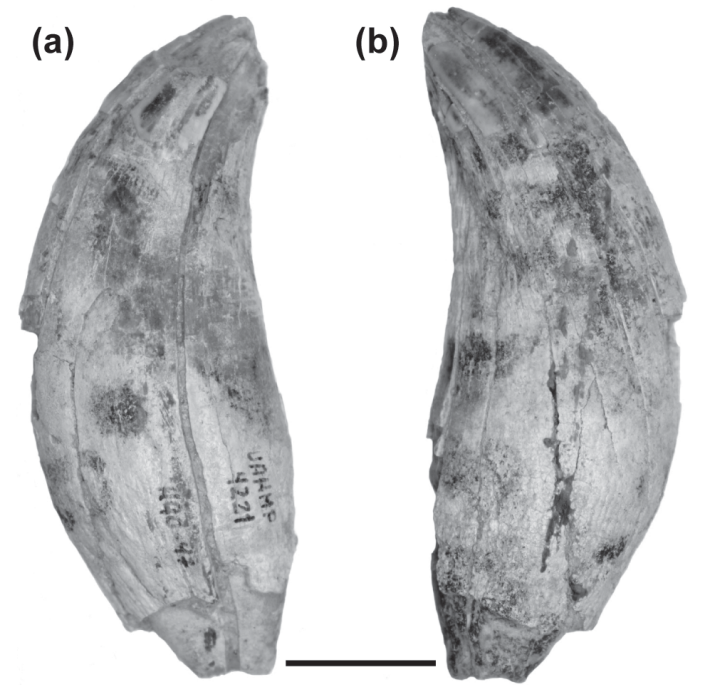

Figure 2. Isolated left lower canine (UAHMP-4221) of Panthera atrox from the late Pleistocene of southeastern Hidalgo, central Mexico. (a) Labial and (b) lingual views. Scale bar equals $2 \mathrm{~cm}$. 
(a)

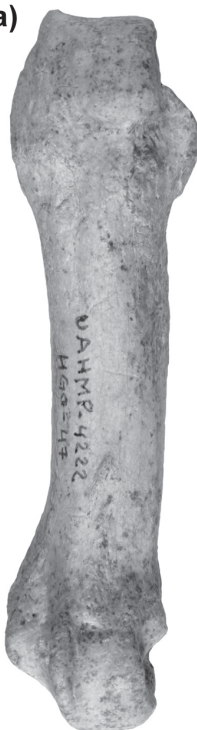

(b)

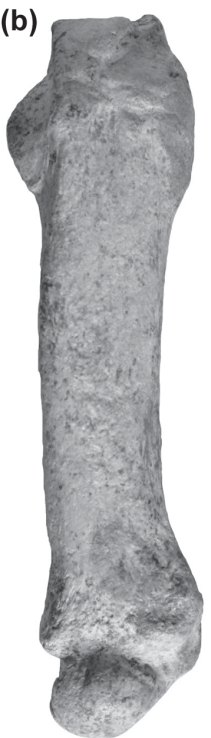

(e) (c)

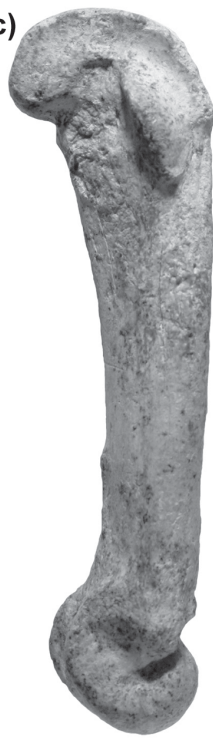

(f) (d)

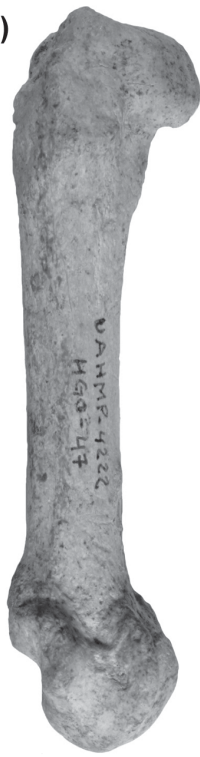

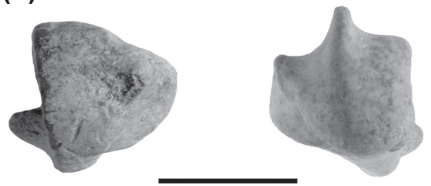

Figure 3. Left fifth metacarpal (UAHMP-4222) of Panthera atrox from the late Pleistocene of southeastern Hidalgo, central Mexico. (a) Ventral, (b) dorsal, (c) medial, (d) lateral, (e) proximal, and (f) distal views. Scale bar equals $2 \mathrm{~cm}$.

Among felids, the morphology of the limb elements is somewhat homogeneous, including the metacarpals. In general, the metacarpal bones of felids are characterized by being short and robust with a broad and curved diaphysis as well as broad proximal and narrow distal ends (MoralesMejía and Arroyo-Cabrales, 2012). All these features are observed in the specimen UAHMP-4222, indicating its felid condition. In particular, the fifth metacarpal from Hidalgo resembles those of Panthera atrox in the following characters: (1) well-developed projection on the palmar side at the proximal end; (2) the articulating surface for the unciform is narrow; (3) the diaphysis is relatively slender; (4) the notch on the articulating surface for the fourth metacarpal is narrow; and (5) the diaphysis at the middle is oval in cross section (Merriam and Stock, 1932). Furthermore, the size of UAHMP-4222 (greatest length $=105.9 \mathrm{~mm}$ ) is within the observed range of fifth metacarpals of $P$. atrox from Rancho La Brea, California, United States (Table 2); however, it is about $25 \%$ larger than the fifth metacarpal of OCMP-077 belonging to $P$. tigris (greatest length $=80.3 \mathrm{~mm}$ ). It should be noted that the fifth metacarpal of Smilodon is distinguished in having a poorly developed projection on the palmar side at the proximal end, a broad articulating surface for the un- ciform, and a relatively stout diaphysis (Merriam and Stock, 1932).

The comparative study indicates that the size and morphology of dental and postcranial remains from Hidalgo are closely comparable to those observed in specimens belonging to Panthera atrox. Hence, the studied sample is formally assigned to that large-sized cat species.

\section{Paleobiological significance}

\subsection{Paleoecology}

The American lion was one of the largest cats that inhabited North America during the late Pleistocene (Kurtén and Anderson, 1980; Lange, 2002). Body size estimations indicate that this felid had a mean body mass of $300 \mathrm{~kg}$, ranging from 200 to $400 \mathrm{~kg}$ (Van Valkenburgh et al., 2016). It has been observed that prey body size tends to increase with the predator size (Sinclair et al., 2003). Therefore, it should be expected that large mammalian herbivores were common prey of Panthera atrox. Van Valkenburgh et al. (2016: fig. 2, p. 865) predicted a typical prey size ranging from 60 to $900 \mathrm{~kg}$ for the American lion, and the maximum prey size could have been about $1000 \mathrm{~kg}$. 


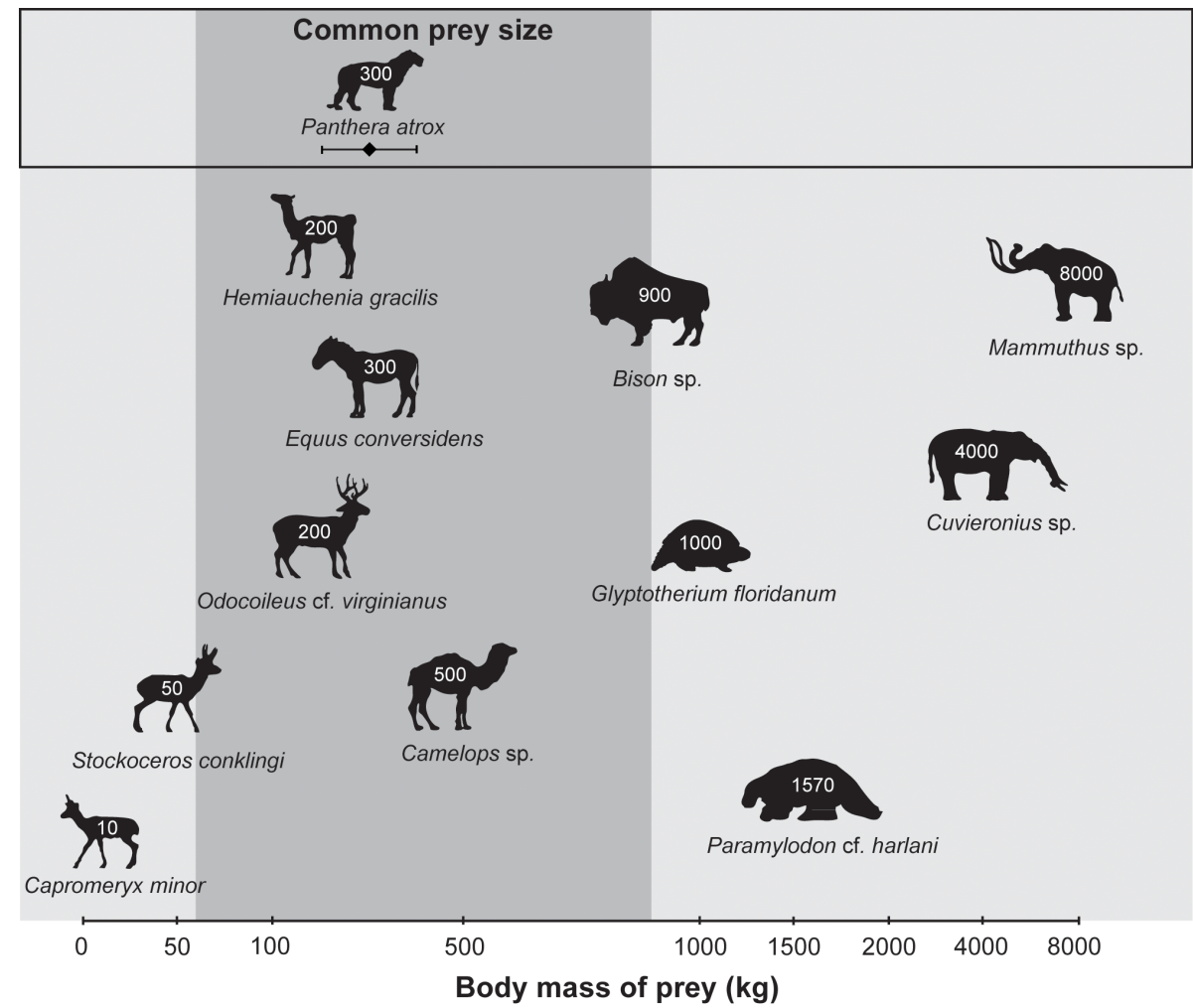

Figure 4. Potential common prey-size range for Panthera atrox from the late Pleistocene of southeastern Hidalgo, including the herbivores that have been reported at the El Barrio locality (HGO-47). Diamond and line indicate the mean and observed range of body mass (from Van Valkenburgh et al., 2016).

Given the above and considering the taxonomic mammalian composition known at the El Barrio locality, it seems that potential prey for Panthera atrox in that site could include adult individuals of llamas (Hemiauchenia gracilis and Camelops sp.), deer (Odocoileus cf. virginianus), horses (Equus conversidens), and even bison (Bison sp.); the body mass among these herbivores is estimated to have been 200 to $900 \mathrm{~kg}$ (Fig. 4). Hunting in groups increases the upper range of available prey size; consequently, it has been suggested that large-sized Pleistocene cats (such as Panthera atrox) were able to kill prey with a body mass of about $6000 \mathrm{~kg}$ (Van Valkenburgh et al., 2016). Assuming a hunting group behavior and potential presence of other individuals belonging to Panthera atrox at southeastern Hidalgo during the late Pleistocene, it is also probable that adult individuals of glyptodonts (Glyptotherium floridanum) and ground sloths (Paramylodon cf. harlani), as well as young and/or subadult individuals of proboscideans (Cuvieronius sp. and Mammuthus sp.), could represent other, perhaps occasional prey.

The American lion was the second largest carnivore in the late Pleistocene ecosystems of North America, exceeded by only the short-faced bear Arctodus simus (Kurtén and Anderson, 1980). The large size and restricted dietary behavior of Panthera atrox (a carnivore that feeds mostly on meat, i.e., a hypercarnivore) suggest that this extinct cat occupied the top of the trophic chain, considering that both conditions are typical of extant top predators (Ritchie and Johnson, 2009). At the El Barrio locality, it is probable that the individual of $P$. atrox described here had the ecological role of the top predator, displacing other carnivores of small to medium size, such as the dire wolf (Canis dirus) to the mesopredator guild.

\subsection{Geographic distribution}

By the late Pleistocene, the American lion was widely distributed from Alaska to southern Mexico. The earliest known occurrences are from the Sangamonian interglacial stage, including localities in the western of the United States, as well as northern and central Mexico (Kurtén and Anderson, 1980; Van Devender et al., 1985), indicating that this large-sized cat reached regions of southern temperate North America in a relatively short time. Subsequently, the American lion spread its distribution to the Great Plains, the Great Basin, the California Coast, the Gulf Coast, and Mexico during the Wisconsinan (Kurtén and Anderson, 1980; Lange, 2002). Based on the known geographic distribution of Panthera atrox, it seems that it was a common inhabitant of temperate areas of central-western North America, although it was able to reach tropical areas that now are part of southern Mexico (Fig. 5). 


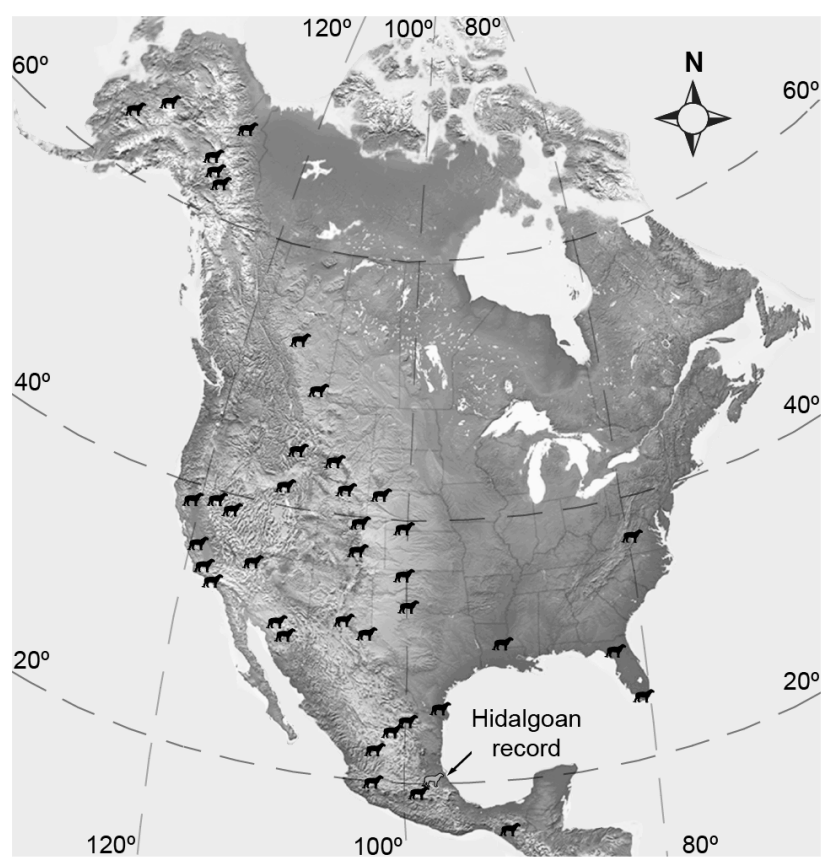

Figure 5. Geographic distribution of Panthera atrox in North America during the late Pleistocene (main source: Kurtén and Anderson, 1980). The gray silhouette indicates the record from southeastern Hidalgo, central Mexico.

Previous to this study, the American lion Panthera atrox has been reported from nine Mexican localities in northern (La Brisca (Sonora); Arroyo-Cabrales et al., 2005), central (San Josecito (Nuevo León), El Cedral (San Luis Potosí), El Cedazo (Aguascalientes), Chapala-Zacoalco (Jalisco), Tequixquiac (State of Mexico); Freudenberg, 1910; Mooser and Dalquest, 1975; Lorenzo and Mirambell, 1981; ArroyoCabrales and Polaco, 2003; Arroyo-Cabrales et al., 2005; Lucas, 2008), and southern (La Simpatía, La Tejería y Villa Corzo (Chiapas); Aviña, 1969; Montellano-Ballesteros and Carbot-Chanona, 2009; Carbot-Chanona and Gómez-Pérez, 2014) areas of the country. The record reported here supplements its presence in central Mexico, specifically in areas that now are part of southeastern Hidalgo. It is noted that most of the localities where Panthera atrox has been reported are located in central Mexico, between 19 and $24^{\circ} \mathrm{N}$ at an altitude from 1500 to $2250 \mathrm{~m}$ a.s.l. (including El Barrio locality at $2184 \mathrm{~m}$ a.s.l., Hidalgo (present study)), whereas the occurrences in northern (La Brisca, Sonora) and southern (Chiapasan localities) Mexico are located at a mean altitude of 750 m a.s.1. (Fig. 6a).

According to the major biogeographic corridors of Ceballos et al. (2010), the records of Panthera atrox from northwestern and central Mexico (including the Hidalgoan record considered in the present study) indicate that this felid used the corridors of the Rocky MountainsSierra Madre Occidental and/or central US-northern Mexico, which correspond to the southern Rocky Mountains-

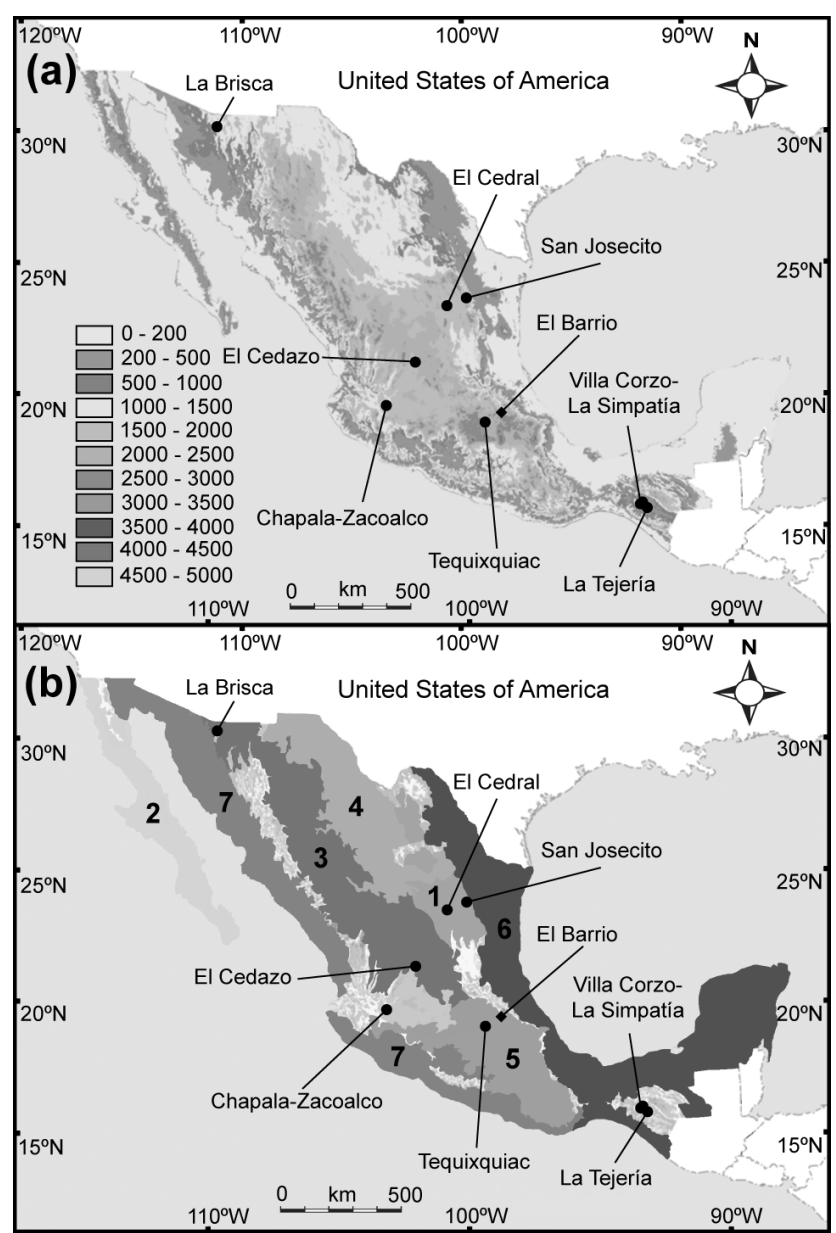

Figure 6. Mexican Pleistocene localities with records of Panthera atrox, considering (a) a hypsometric base and (b) the Mexican biogeographic corridors (sensu Ceballos et al., 2010). Diamond indicates the record from southeastern Hidalgo, central Mexico. Biogeographic corridors: 1, eastern US-Sierra Madre Oriental; 2, western US-Baja California; 3, Rocky Mountains-Sierra Madre Occidental; 4, central US-northern Mexico; 5, Transvolcanic BeltSierra Madre del Sur; 6, Tamaulipas-Central America Gulf Lowlands; and 7, Sonora-Central America Pacific Lowlands.

Sierra Madre Occidental branch and to the Great Plainswestern Chihuahua/Central Plateau corridors, respectively (after Ferrusquía-Villafranca et al., 2010). Furthermore, it used the corridor of the Tamaulipas - Central America Gulf Lowlands (i.e., Gulf Coastal Plain corridor (after FerrusquíaVillafranca et al., 2010)) for reaching southern tropical areas of the Mexican territory (Fig. 6b).

\section{Review of the felid record from the Pleistocene of Mexico}

In Mexico, Pleistocene felid fossils are uncommon and fragmentary. Nevertheless, this group of carnivores was relatively diverse, including seven genera (Felis, Miraci- 
Table 3. The record of felids from the Pleistocene of Mexico. The morphotectonic provinces are those of Ferrusquía-Villafranca (1993). Morphotectonic provinces: NW, Northwestern Plains and Sierras; CH-CO, Chihuahua-Coahuila Plateaus and Ranges; SMOr, Sierra Madre Oriental; CeP, Central Plateau; TMVB, Trans-Mexican Volcanic Belt; GCP, Gulf Coastal Plain; SMS, Sierra Madre del Sur; CHI, Sierra Madre de Chiapas; YPL, Yucatan Platform. Localities: 1, El Golfo (Sonora); 2, La Brisca (Sonora); 3, Terapa (Sonora); 4, Cuatro Ciénegas (Coahuila); 5, Cueva de Jiménez (Chihuahua); 6, Cueva de San Josecito (Nuevo León); 7, El Cedral (San Luis Potosí); 8, Mina San Antonio (San Luis Potosí); 9, El Cedazo (Aguascalientes); 10, Chapala-Zacoalco (Jalisco); 11, Tequixquiac (State of Mexico); 12, Tlapacoya (State of Mexico); 13, Tlailotlacan (State of Mexico); 14, El Barrio (Hidalgo, present study); 15, Valsequillo (Puebla); 16, Mixtequilla (Veracruz); 17, San Agustín (Oaxaca); 18, La Simpatía (Chiapas); 19, La Tejería (Chiapas); 20, Villa Corzo (Chiapas); 21, Cueva de Loltún (Yucatán); 22, Hoyo Negro (Quintana Roo).

\begin{tabular}{|c|c|c|c|c|c|c|c|c|c|c|c|c|c|c|c|c|c|c|c|c|c|c|}
\hline \multirow[b]{2}{*}{ Taxa } & \multicolumn{3}{|c|}{ NW } & \multicolumn{2}{|c|}{$\mathrm{CH}-\mathrm{CO}$} & \multicolumn{3}{|c|}{ SMOr } & \multirow{2}{*}{$\begin{array}{c}\mathrm{CeP} \\
9\end{array}$} & \multicolumn{6}{|c|}{ TMVB } & \multirow{2}{*}{$\begin{array}{c}\text { GCP } \\
16\end{array}$} & \multirow{2}{*}{$\begin{array}{c}\text { SMS } \\
17\end{array}$} & \multicolumn{3}{|c|}{$\mathrm{CHI}$} & \multicolumn{2}{|c|}{ YPL } \\
\hline & 1 & 2 & 3 & 4 & 5 & 6 & 7 & 8 & & 10 & 11 & 12 & 13 & 14 & 15 & & & 18 & 19 & 20 & 21 & 22 \\
\hline Panthera atrox & & $\mathrm{X}$ & & & & $\mathrm{X}$ & $\mathrm{X}$ & & $\mathrm{X}$ & $\mathrm{X}$ & $\mathrm{X}$ & & & $\mathrm{X}$ & & & & $\mathrm{X}$ & $\mathrm{X}$ & $\mathrm{X}$ & & \\
\hline Panthera onca & & $\mathrm{X}$ & & $\mathrm{X}$ & & $\mathrm{X}$ & & $\mathrm{X}$ & $\mathrm{X}$ & $\mathrm{X}$ & & & & & & & & & & & & \\
\hline Panthera cf. P. onca & $\mathrm{X}$ & & & & & & & & & & & & & & & & & & & & & \\
\hline Puma concolor & & & & $\mathrm{X}$ & $\mathrm{X}$ & $\mathrm{X}$ & & & & $\mathrm{X}$ & $\mathrm{X}$ & & & & & $\mathrm{X}$ & $\mathrm{X}$ & & & & $\mathrm{X}$ & \\
\hline Puma yagouaroundi & & & & & & $\mathrm{X}$ & & & & & & & & & & & & & & & $\mathrm{X}$ & \\
\hline Lynx rufus & & & $\mathrm{X}$ & $\mathrm{X}$ & $\mathrm{X}$ & $\mathrm{X}$ & & $\mathrm{X}$ & $\mathrm{X}$ & & $\mathrm{X}$ & $\mathrm{X}$ & & & & & & & & & & \\
\hline Leopardus pardalis & & & & & & & & & & & & & & & & & & & & & $X$ & \\
\hline Leopardus wiedii & & & & & & & & & & & & & $\mathrm{X}$ & & & & & & & & & \\
\hline Smilodon fatalis & & & & & & $\mathrm{X}$ & & & $\mathrm{X}$ & $X$ & $\mathrm{X}$ & & & & & & & & & & & $\mathrm{X}$ \\
\hline Smilodon sp. & & & & & & & & & & & & & & & $\mathrm{X}$ & & & & & & & \\
\hline Felis rexroadensis & $\mathrm{X}$ & & & & & & & & & & & & & & & & & & & & & \\
\hline Miracinonyx inexpectatus & $\mathrm{X}$ & & & & & & & & & & & & & & & & & & & & & \\
\hline
\end{tabular}

nonyx, Panthera, Puma, Lynx, Leopardus, and Smilodon) and 11 species (Felis rexroadensis, Miracinonyx inexpectatus, Panthera atrox, Panthera onca, Puma concolor, Puma yagouaroundi, Lynx rufus, Leopardus pardalis, Leopardus wiedii, Smilodon fatalis, and Smilodon gracilis) (Table 3). The Mexican record of Pleistocene felids includes $87.5 \%$ and $73.3 \%$ of generic and specific diversity known for North America, respectively.

As far as we know, the only record of felids from the early Pleistocene of Mexico consists of three species ( $\mathrm{Fe}$ lis rexroadensis, Miracinonyx inexpectatus, and Panthera cf. P. onca) from El Golfo, State of Sonora, in the Northwestern Plains and Sierras morphotectonic province (Lindsay, 1984; Croxen III et al., 2007). By contrast, the late Pleistocene record of Mexican felids is represented by at least eight species whose material has been recovered from several localities across the country (Fig. 7).

Fossil material that has been referred to Panthera atrox (the American lion), P. onca (jaguar), Lynx rufus (bobcat), Puma concolor (cougar), and Smilodon fatalis (sabertoothed cat) is somewhat numerous. These species are known from several late Pleistocene localities in the following morphotectonic provinces: Northwestern Plains and Sierras $(P$. atrox and P. onca; Arroyo-Cabrales et al., 2005; FerrusquíaVillafranca et al., 2010), Chihuahua-Coahuila Plateaus and Ranges (P. onca, L. rufus, and P. concolor; Gilmore, 1947; Messing, 1986), Sierra Madre Oriental (P. atrox, P. onca, L. rufus, P. concolor, and S. fatalis; Lorenzo and Mirambell, 1981; Arroyo-Cabrales and Álvarez, 2003; ArroyoCabrales et al., 2005, 2010; Ferrusquía-Villafranca et al., 2010), Central Plateau (P. atrox, P. onca, L. rufus, and $S$. fatalis; Mooser, 1959; Mooser and Dalquest, 1975), TransMexican Volcanic Belt (P. atrox, P. onca, P. concolor, and $S$. fatalis; Freudenberg, 1910; Aviña, 1969; Rufolo, 1998; Lucas, 2008; Ferrusquía-Villafranca et al., 2010), Gulf Coastal Plain (P. concolor; Arroyo-Cabrales et al., 2005; FerrusquíaVillafranca et al., 2010), Sierra Madre del Sur (P. concolor; Arroyo-Cabrales et al., 2005; Ferrusquía-Villafranca et al., 2010), Sierra Madre de Chiapas (P. atrox; MontellanoBallesteros and Carbot-Chanona, 2009; Carbot-Chanona and Gómez-Pérez, 2014), and Yucatan Platform (P. concolor and S. fatalis; Álvarez and Polaco, 1982; Collins et al., 2015). The present study adds an occurrence of Panthera atrox from a late Pleistocene locality in southeastern Hidalgo, central Mexico, within the Trans-Mexican Volcanic Belt morphotectonic province.

The species Puma yagouaroundi (jaguarondi) is known from the Sierra Madre Oriental and Yucatan Platform morphotectonic provinces (Arroyo-Cabrales and Johnson, 1998; Arroyo-Cabrales and Álvarez, 2003). By the same token, the species Leopardus pardalis (ocelot) and a saber-tooth cat with an uncertain specific identity (referred to as Smilodon cf. $S$. gracilis) have single occurrences from localities in the Yucatan Platform and Trans-Mexican Volcanic Belt morphotectonic provinces, respectively (Kurtén, 1967; ArroyoCabrales and Álvarez, 2003; Ferrusquía-Villafranca et al., 2010).

There is a report of Leopardus wiedii from a site known as Tlailotlacan, late Pleistocene of the State of Mexico (ArroyoCabrales et al., 2005, 2010). Furthermore, there are mentions of Smilodon sp., Panthera sp., and Lynx sp. from localities in the Sierra Madre Oriental (Smilodon sp.; Arroyo-Cabrales et 


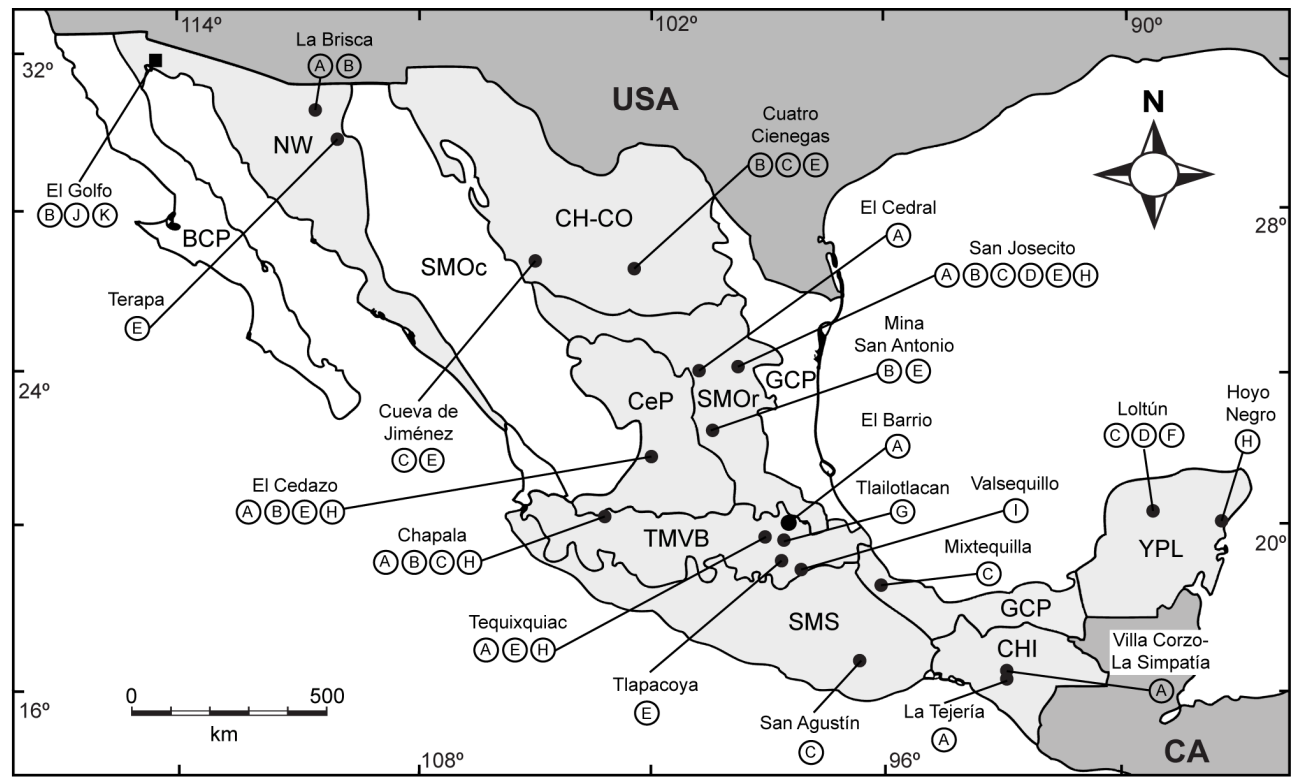

Figure 7. Mexican Pleistocene localities with records of felids. The map is regionalized in the morphotectonic provinces of FerrusquíaVillafranca (1993). Abbreviations of the morphotectonic provinces as in Table 3. Squares indicate the early Pleistocene localities and circles the late Pleistocene localities. The felid record includes the following species: A: Panthera atrox; B: Panthera onca; C: Puma concolor; D: Puma yagouaroundi; E: Lynx rufus; F: Leopardus pardalis; G: Leopardus wiedii; H: Smilodon fatalis; I: Smilodon cf. S. gracilis; J: Felis rexroadensis; K: Miracinonyx inexpectatus.

al., 2005) and Trans-Mexican Volcanic Belt morphotectonic provinces (Smilodon sp., Panthera sp., and Lynx sp.; ArroyoCabrales et al., 2005; Bravo-Cuevas et al., 2009).

Clearly, felids were more diverse and widespread in their geographic distribution across the Mexican territory during the late Pleistocene. There are several areas in northern, central, and southern Mexico that testify to the presence of three to four species of felids, including Cuatro Ciénegas, Coahuila ( $P$. onca, P. concolor, and L. rufus); El Cedazo, Aguascalientes (P. atrox, P. onca, L. rufus, and S. fatalis); Chapala-Zacoalco, Jalisco (P. atrox, P. onca, P. concolor, and S. fatalis), Tequixquiac, State of Mexico (P. atrox, L. rufus, and S. fatalis); and Cueva de Loltún, Yucatán, (P. concolor, P. yagouaroundi, and L. pardalis). The San Josecito Cave locality testifies to the presence of six species of felids. It is probable that the high diversity recorded there should be related to the nature of the site, which functioned as a shelter for maternity, resting, and/or feeding of several carnivore groups, including felids (Arroyo-Cabrales and Álvarez, 2003).

\section{Conclusions}

An isolated lower canine and a fifth metacarpal bone recovered from fluvial Quaternary deposits in southeastern Hidalgo, central Mexico, are formally described and assigned to Panthera atrox. A comparative study indicates that the Hidalgoan specimens share with that species the following di- agnostic features: a large, robust, and non-strongly curved lower canine; a large and relatively slender fifth metacarpal with a well-developed projection on the palmar side at the proximal end; a narrow articulating surface for the unciform; a narrow notch on the articulating surface for the fourth metacarpal; and a diaphysis that at the middle is oval in cross section. The recovery of the American lion at the El Barrio locality suggests that this large-sized hypercarnivore was the top predator of the mammalian communities that inhabited southeastern Hidalgo during the late Pleistocene. In addition, it seems that some areas that now are part of central Mexico were suitable hunting sites for members of $P$. atrox, considering the high diversity of large mammalian herbivores (body mass $\geq 200 \mathrm{~kg}$ ) that have been recorded there. In addition, Panthera atrox was relatively common in temperate areas of central Mexico between 19 and $24^{\circ} \mathrm{N}$.

The Pleistocene record of Felidae from Mexico encompasses 87.5 and $73.3 \%$ of total generic and specific felid diversity, respectively, known for North America.

Acknowledgements. We are indebted to Blaire Van Valkenburgh and Ismael Ferrusquía Villafranca for their comments and suggestions, which greatly improved the final version of the manuscript. The first author thanks Aisling Farrell, collection manager of the Page Museum, La Brea Tar Pits, for her kind support during his visit to that collection. Thanks to Florian Witzmann and Anna Wenzel for their help along the editing and handling process of the manuscript. Last but not least, thanks to the Museum für Naturkunde in Berlin for defraying the article-processing charges. 
Edited by: F. Witzmann

Reviewed by: B. Van Valkenburgh and I. Ferrusquía-Villafranca

\section{References}

Alvarez, T. and Polaco, O. J.: Restos de moluscos y mamíferos cuaternarios procedentes de Loltún, Yucatán, Cuaderno de Trabajo del Departmento de Prehistoria, INAH, México, 26, 1-41, 1982.

Arroyo-Cabrales, J. and Alvarez, S. T.: A preliminary report of the Late Quaternary mammal fauna from Loltún Cave, Yucatán, México, in: Ice age cave faunas of North America, edited by: Schubert, B. W., Mead, J. I., and Graham, R. W., Indiana University Press and Denver Museum of Nature and Science, Denver, Colorado, 262-272, 2003.

Arroyo-Cabrales, J. and Johnson, E.: 1998, La Cueva de San Josecito, Nuevo León, México: Una primera interpretación paleoambiental, in: Avances en Investigación, Publicación Especial 1. Paleontología de Vertebrados, edited by: Carranza-Castañeda, O. and Córdoba-Méndez, D. A., Universidad Autónoma del Estado de Hidalgo, Centro de Investigaciones en Ciencias de la Tierra, Pachuca, Hidalgo, México, 120-126, 1998.

Arroyo-Cabrales, J. and Polaco, O. J.: Caves and the Pleistocene vertebrate paleontology of Mexico, in: Ice age cave faunas of North America, edited by: Schubert, B. W., Mead, J. I., and Graham, R. W., Indiana University Press and Denver Museum of Nature and Science, Denver, Colorado, 273-291, 2003.

Arroyo Cabrales, J., Polaco, O. J., and Johnson, E.: La mastofauna del Cuaternario tardío de México, in: Bases de datos SNIBCONABIO, Proyecto No. G012, INAH, México, 2005.

Arroyo-Cabrales, J., Polaco, O. J., Johnson, E., and FerrusquíaVillafranca, I.: A perspective on mammal biodiversity and zoogeography in the late Pleistocene of Mexico, Quatern. Int., 212, 187-197, 2010.

Aviña, C. E.: Nota sobre carnívoros fósiles del Pleistoceno de México, Departamento de Prehistoria, INAH, Paleoecología, 5, 1-20, 1969.

Barnett, R., Shapiro, B., Barnes, I., Ho, S. Y. W., Burger, J., Yamaguchi, N., Higham, T. F. G., Wheeler, T., Rosendhal, W., Sher, A. V., Sotnikova, M., Kuznetsova, T., Baryshnikov, G. F., Martin, L. D., Harington, C. R., Burns, J. A., and Cooper, A.: Phylogeography of lions (Panthera leo spp.) reveals three distinct taxa and a late Pleistocene reduction in genetic diversity, Mol. Ecol., 18, 1668-1677, 2009.

Bell, C. J., Lundelius Jr., E. L., Barnosky, A. D., Graham, R. W., Lindsay, E. H., Ruez Jr., D. R., Semken Jr., H. A., Webb, S. D., and Zakrzewski, R. J.: The Blancan, Irvingtonian, and Rancholabrean mammal ages, in: Late Cretaceous and Cenozoic mammals of North America, edited by: Woodburne, M. O., Columbia University Press, New York, 232-314, 2004.

Bowditch, T. E.: An analysis of the natural classifications of Mammalia for the use of students and travellers, J Smith, Paris, 115 pp., 1821.

Bravo-Cuevas, V. M.: Pleistocene faunal assemblage from southcentral region of the state of Hidalgo, Central Mexico, Sixty-First Annual Meeting Society of Vertebrate Paleontology, Museum of the Rockies Montana State University, Bozeman, Montana, 3-6
October 2001, J. Vertebr. Paleontol. 21 (Supplement to No. 3), 35A, 2001.

Bravo-Cuevas, V. M.: Diferenciación geológica y bioestratigráfica de la Formación Tarango para el estado de Hidalgo, Centro de México, México, Hidalgo, Universidad Autónoma del Estado de Hidalgo, Centro de Investigaciones en Ciencias de la Tierra, Technical Report, 59 pp., 2002.

Bravo-Cuevas, V. M., Cabral-Perdomo M. A., Ortiz-Caballero E., and Priego Vargas J.: La Megafauna del Pleistoceno, in: Los Fósiles del Estado de Hidalgo, edited by: González-Rodríguez, K. A., Cuevas-Cardona, C., and Castillo-Cerón, J. M., Universidad Autónoma del Estado de Hidalgo, Pachuca, Hidalgo, México, 85-96, 2009.

Bravo-Cuevas, V. M., Jiménez-Hidalgo, E., and Priego-Vargas, J.: Taxonomía y hábito alimentario de Equus conversidens (Perissodactyla, Equidae) del Pleistoceno Tardío (Rancholabreano) de Hidalgo, centro de México, Rev. Mex. Cienc. Geol., 28, 65-82, 2011.

Bravo-Cuevas, V. M., Jiménez-Hidalgo, E., Cuevas-Ruíz G., and Cabral-Perdomo, M. A.: A small Hemiauchenia from the late Pleistocene of Hidalgo, central Mexico, Acta Palaeontol. Pol., 57, 497-508, 2012.

Bravo-Cuevas, V. M., Jiménez-Hidalgo, E., Cabral-Perdomo, M. A., and Priego-Vargas, J.: Taxonomy and notes on the paleobiology of the late Pleistocene (Rancholabrean) antilocaprids (Mammalia, Artiodactyla, Antilocapridae) from the state of Hidalgo, central Mexico, Rev. Mex. Cienc. Geol., 30, 601-613, 2013.

Carbot-Chanona, G. and Gómez-Pérez, L. E.: Nueva evidencia de Panthera atrox (Mammalia, Felidae) en el Pleistoceno Tardío de Chiapas, Lacandonia, 8, 83-89, 2014.

Ceballos, G., Arroyo-Cabrales, J., and Ponce, E.: Effects of Pleistocene environmental changes on the distribution and community structure of the mammalian fauna of Mexico, Quaternary Res., 73, 464-473, 2010.

Christiansen, P. and Harris, J. M.: Craniomandibular morphology and phylogenetic affinities of Panthera atrox: implications for the evolution and paleobiology of the lion lineage, J. Vertebr. Paleontol., 29, 934-945, 2009.

Collins, S. V., Reinhardt, E. G., Rissolo, D., Chatters, J. C., Blank, A. N., and Erreguerena, P. L.: Reconstructing water level in Hoyo Negro, Quintana Roo, Mexico, implications for early Paleoamerican and faunal access, Quaternary Sci. Rev., 124, 68-83, 2015.

Croxen III, F. W., Shaw, C. A., and Sussman, D. R.: Pleistocene Geology and Paleontology of the Colorado River Delta at Golfo de Santa Clara, Sonora, Mexico, Wild, Scenic and Rapid: A Trip Down the Colorado River Trough, 84-89, 2007.

Davis, B. W., Li, G., and Murphy, W. J.: Supermatrix and species tree methods resolve phylogenetic relationships within the big cats, Panthera (Carnivora: Felidae), Mol. Phylogenet. Evol., 56, 64-76, 2010.

Ferrusquía-Villafranca, I., Arroyo-Cabrales, J., MartínezHernández, E., Gama-Castro, J., Ruiz-González, J., Polaco, O. J., and Johnson, E.: Pleistocene mammals of Mexico: A critical review of regional chronofaunas, climate change response and biogeographic provinciality, Quatern. Int., 217, 53-104, 2010.

Fischer von Waldheim, G.: Adversaria zoologica, Mem. Soc. Natural. Mosc., 5, 368-428, 1817. 
Freudenberg, W.: Die säugetierfauna des Pliocäns und post-Pliocäns von Mexiko. 1. Carnivoren, Geol. und Palaont. Abhandlungen, 9, 195-231, 1910.

Gilmore, R. M.: Report on a collection of mammal bones from archeologic cave-sites in Coahuila, Mexico, J. Mamma., 28(2), 147-165, 1947.

Instituto Nacional de Estadística, Geografía e Informática (INEGI): Síntesis Geográfica del estado de Hidalgo, Instituto Nacional de Estadística, Geografía e Informática, México, 134 pp., 1992.

IUCN Red List of Threatened Species, Version 2015-4, available at: http://www.iucnredlist.org, last access: 11 April 2016.

Johnson, W. E., Eizirik, E., Pecon-Slattery, J., Murphy, W. J., Antunes, A., Teeling, E., and O'Brien, S. J.: The Late Miocene radiation of modern Felidae: a genetic assessment, Science, 311, 73-77, 2006.

King, L. M. and Wallace, S. C.: Phylogenetics of Panthera, including Panthera atrox, based on craniodental characters, Hist. Biol.: An International Journal of Paleobiology, 26, 827-833, 2014.

Kurtén, B.: Präriew und Sabelzahntiger aus dem Pleistozän des Valsequillo, Mexiko, Quärter, 18, 173-178, 1967.

Kurtén, B.: Pleistocene mammals of Europe, Aldine Transaction A Division of Transaction Publishers, New Brunswick (USA) and London (UK), 317 pp., 2009.

Kurtén, B. and Anderson, E.: Pleistocene mammals of North America, Columbia University Press, New York, 442 pp., 1980.

Lange, I. M.: Ice Age mammals of North America, Mountain Press Publishing Company, Missoula, Montana, 226 pp., 2002.

Leidy, J.: Description of an extinct species of American lion: Felis atrox, T. Am. Philos. Soc. New Series, 10, 319-321, 1853.

Lindsay, E. H.: Late Cenozoic mammals from northwestern Mexico: J. Vertebr. Paleontol., 4, 208-215, 1984.

Lorenzo, J. L. and Mirambell, L.: El Cedral, S.L.P., Mexico: Un sitio con presencia humana de más de 30,000 aP, in: X Congreso de la Unión Internacional de Ciencias Prehistóricas y Protohistóricas: Comisión XII: El Poblamiento de América. Coloquio: Evidencia arqueológica de ocupación humana en América anterior a 11,500 años a.p., edited by: Bryan, A. L., Unión Internacional de Ciencias Prehistóricas y Protohistóricas, México, 18-24 October 1981, 11112-11124, 1981.

Lucas, S. G.: Late Cenozoic fossil mammals from the Chapala rift basin, Jalisco, Mexico, in: Neogene mammals: New Mexico, USA, edited by: Lucas, S. G., Morgan, G. S., Spielmann, J. A., and Prothero, D. R., New Mexico Museum of Natural History and Science Bulletin, 44, 39-49, 2008.

Mazák, J. H.: What is Panthera palaeosinensis?, Mammal Rev., 40, 90-102, 2010.
Merriam, J. C. and Stock, C.: The Felidae of Rancho La Brea: Carnegie Institution of Washington, Washington, 231 pp., 1932.

Messing, H. J.: A late Pleistocene-Holocene fauna from Chihuahua, Mexico, Southwest. Nat., 31, 277-288, 1986.

Montellano-Ballesteros, M. and Carbot-Chanona, G.: Panthera leo atrox (Mammalia: Carnivora: Felidae) in Chiapas, Mexico, Southwest. Nat., 54, 217-222, 2009.

Mooser, O.: La fauna "Cedazo" del Pleistoceno en Aguascalientes, Ann. Inst. Biol. México, 29, 409-452, 1959.

Mooser, O. and Dalquest, W. W.: Pleistocene mammals from Aguascalientes, central Mexico, J. Mammal., 56, 781-820, 1975.

Morales-Mejía, F. M. and Arroyo-Cabrales, J.: Estudio comparativo de algunos elementos de las extremidades de las familias Felidae y Canidae (Mammalia, Carnivora), Rev. Esp. Cienc. QuímicoBiológicas, 15, 75-84, 2012.

Oken, L.: Lehrbuch der Naturgeschichte, Thiel 3. Zoologie, Leipzig, C. H. Reclam, 2, 1-1270, 1816.

Paleobiology Database: https://paleobiodb.org/, last access: 11 April 2016.

Pockock, R. I.: The classification of existing Felid, Ann. Mag. Nat. Hist., 20, 320-350, 1917.

Ritchie, E. G. and Johnson, C. N.: Predator interactions, mesopredator release and biodiversity conservation, Ecol. Lett., 12, 982998, 2009.

Rufolo, S. J.: Taxonomy and significance of the fossil mammals of Lake Chapala, Jalisco, Mexico, M.S. thesis, Provo, Utah, Brigham Young University, 146 pp., 1998.

Salles, L. O.: Felid phylogenetics: extant taxa and skull morphology (Felidae, Aeluroidea), Am. Mus. Novit., 3047, 1-67, 1992.

Simpson, G. G.: Large Pleistocene felines of North America, Am. Mus. Novit., 1136, 1-27, 1941.

Sinclair, A. R. E., Mduma, S., and Brashares, J. S.: Patterns of predation in a diverse predator-prey system, Nature, 425, 288-290, 2003.

Tseng, Z. J., Wang, X., Slater, G. J., Takeuchi, G. T., Li, Q., Liu, J., and Xie, G.: Himalayan fossils of the oldest known pantherine establish ancient origin of big cats, Proc. R. Soc. B, 281, 20132686, doi:10.1098/rspb.2013.2686, 2016.

Van Devender, T. R., Rea, A. M., and Smith, M. L.: The Sangamon interglacial vertebrate fauna from Rancho la Brisca, Sonora, Mexico, T. San Diego Soc. Nat. Hist., 21, 23-55, 1985.

Van Valkenburgh, B., Hayward, M. W., Ripple, W. J., Meloro, C., and Roth, V. L.: The impact of large terrestrial carnivores on Pleistocene ecosystems, Proc. Natl. A. Sci., 113, 862-867, 2016.

Whitmore Jr., F. C. and Foster, H. L.: Panthera atrox (Mammalia: Felidae) from central Alaska, J. Paleontol., 247-251, 1967. 